\title{
法整備による超高齢社会の介護システムの確立 一日英法比較研究—
}

\author{
APPROACH OF THE ESTABLISHED CARE SYSTEM ON THE AGED SOCIETY \\ BY DEVELOPING THE REGULATIONS \\ COMPARATIVE STUDY BETWEEN BRITISH AND JAPANESE REGULATIONS
}

\author{
滝沢茂男 $^{1} \cdot$ 武藤佳恭 $^{2}$
}

${ }^{1}$ M.A.（社会技術）慶應義塾大学SFC上席研究員（訪問） (E-mail:takizawa@civilnet.org)

${ }^{2}$ Ph.D. (情報工学) 慶應義塾大学環境情報学部教授 (E-mail: takefuji@sfc.keio.ac.jp)

人口の $25 \%$ 高齢者が占める超高齢社会を迎え, 高齢者の 5 人に一人が要支援や要介護になる. 介護は 人と人との間での行為であり, 在宅介護に入るへルパーの 8 割が腰痛に悩まされている. 年齢状況を問わ ず，介護者の健康管理により，介護労災を防ぎ，介護力を高めることは，在宅の老々介護を可能にし，超 高齢社会を安定的に維持するために重要である. 顕著な筋骨格疾病減少を実現した英国法律を調査し, 法 整備とその執行についてわが国と比較した。わが国の筋骨格疾病減少へ向けた介護現場における意識, 対 策やその現状を調查し，明らかにした。これらの研究結果から，現状の法体系のままでは，わが国におけ る看護・介護現場の筋骨格疾病減少は期待できないことが分かり, 法整備の必要性を述べた。

キーワード : 法整備, 介護労災, 筋骨格疾病減少, 超高齢社会, 社会崩壊防止

\section{1. 研究の背景と目的}

（1）研究の背景 : 超高齢社会の到来

1960 年頃は先進国中の最下位であったわが国の平均 寿命は, 平成 16 年厚生労働省による簡易生命表では女性 が 85.59 歳, 男性が 78. 64 歳で男女共世界一であり，世 界最速のペースで長寿化が進んでいる. 今後, 日本人の 平均余命が 90 歳を超えない確立はわずか 6 分の 1 とする 米戦略国際問題研究所の予測もある. ${ }^{1)}$ 益々高齢者と高 齢障害者は増加する.

2000 年に，山口県大島郡東和町は高齢化率が $50.02 \%$ に達したと報じられた．今後こうした地方自治体の増加 は避けられない. 高齢者人口比率が高い県は現在, 過疎 が進む各県とされているが，今後団塊世代の高齢化に伴 い，大都市部での高龄化が急速に進む. その現状は「高 齢化率が 20.0 \%を超えた」2） と内閣府へ報告された事 実に現れている. 65 歳以上が $25 \%$ を超えた社会, 超高 齢社会到来は, 介護保険導入当初の 2025 年の予測から 2015 年くらいに大幅に早まるのである.

そうした超高齢社会で起きるであろう事態を三重県に 見ることができる. 三重県高齢者人口に占める要介護(支 援）高齢者数の割合は，県全体で 2001 年の $12.8 \%$ に対 して 2007 年には $16.6 \%$ と, 非常に高い伸びを示した.

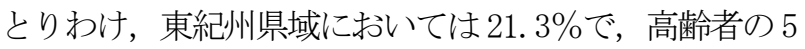
人に 1 人が要支援や要介護が必要になった. ${ }^{3)}$ 同報告で
は, 現在でも「老々介護」は珍しくなく,「介護施設の拡 充」と「介護者の養成・資質向上」は急務としていると している.

財政に関し, まず年金について述べる. 賦課方式の年金 制度は，ねずみ講のようであり，団塊世代は支え手であ った. 公的年金が現制度を維持していけば，子孫という 新規加入者が少子化現象により減少し, 年老いた団塊世 代すなわち受け取る者が増えて破綻する.

次に医療保険料に関して，2000 年に旧厚生省は「高齢 化で今後も拠出金, 保険給付金が増えるため, 市町村国 保の財政は一層㛜しい状態になる」と予測した. 被介護 者の増加, 高齢化による医療費の増加は, 年老いた団塊 世代を直撃する. 自営業者などが加入する国民健康保険 (国保)の 2004 年度収支決算の概要では, 収入 5 兆 5, 709 億円に対し，支出 5 兆 7, 416 億円となり，1，707 億円の 赤字となった. さらに社会保障給付費は 2006 年度 89 兆 8000 億円で, 25 年度には 1 ・ 57 倍の 141 兆円に達すると の推計を厚生労働省として正式に公表した.

介護保険の先進国ドイツを見ると, 公的介護保険制度 は, 1999 年以来赤字が拡大し, 介護費用の高騰と, 保険 料収入の大幅な減少により, 2003 年度の赤字は前年に比 ベて 84\%も増加し， 7 億ユーロ（910 億円）と創設以来 最悪の数字を記録した. ドイツ健康省によると, 2005 年 末に赤字額が 9 億ユーロに達し, 2006 年の末には流動性 を確保するためのリザーブ (準備金) が底をつく．この 
ためドイツ介護保険制度は,創設から 10 年にして抜本的 な改革が避けられない状態に追い込まれている。

我が国の介護保険制度でも, 2003 年度に介護保険から 支払われた介護サービス費は 5 兆 6795 億円となり, 2000 年度における支給額 3 兆 2, 291 億円から 57\%増えた. サ ービスを提供する民間企業などの参入が進んだため在宅 サービスの費用は 2 兆 3,568 億円に達した. 在宅サービ スの介護サービス全体に占める比率は介護保険が発足し た 2000 年度 (33.9\%) から伸び続け，46.5\%に達した. ${ }^{5)}$ 2004 年度に介護保険財政が赤字に陥った市町村と広域 連合は全体の $13 \%, 290$ 団体となり 2003 年度の 170 団体 の 1.7 倍に増えた. ${ }^{6)}$ 年金・ (医療・介護) 保険料ばかり でなく, 介護施設の拡充と介護者の養成は厚生労働省の 発表した社会保障給付費の増加をもたらした.

国民の収入の大きなウエイトを占める給与所得は, 2003 年の民間の給与総額は 201 兆 7,742 億円 (同 $\mathbf{\Delta} 0.9 \%$, 1 兆 9,085 億円の減少）で, 7 年続けて減少している. ${ }^{7)}$ 今後も大きな伸びは望めない，また日本経済新聞社が家 族を介護している全国の男女 400 人一行った調査に関し,

「介護の総費用は在宅なら月平均 4 万 2000 円, 施設に入 れば 10 万 2500 円」と報じられた. ${ }^{8)}$ 三重県からは「介 護施設の拡充』と『介護者の養成・資質向上』は急務」 と報告されているが，以上から特に「介護施設の拡充」 の限界は明らかになっている。

(2) 研究の目的

超高齢社会では, 高齢者の 5 人に 1 人が日常生活に支 援や介護が必要になる. 家庭内の老々介護に関していえ ば,「現在でも『老々介護』は珍しくなく」と報告されて いるが，普遍化することは明らかである．また「在宅サ ービスは伸び続け，2003 年度は $46.5 \%$ に達した.」こと から, 在宅要介護者を介護する介護労働者も増加する. 介護は人と人との間での行為であり, 福祉用具の普及も あるが，望月は『全て人の手』といっても過言でない， 介護職に携わる人たちは，身体的なストレスが溜りやす く, 特に在宅介護に入るへルパーの 8 割が腰痛に悩まさ れている.」9) としている.

高齢者や高齢障害者に対する「介護予防」は制度化さ $れ^{10)}$, 重要な国家政策の一つとなった。 しかし介護す る側, 特に介護者の健康管理については見失われがちだ った. 介護者の健康管理は, 介護サービスの質的向上や 量的拡大と不可分といえる. 老々介護の状況を思いやる だけで，その重要さに思いが至るが，その実態の解明と 予防対策の確立は十分ではない，一例としての介護者の 腰痛に関しても, 発生頻度も高く, 非常に深刻な問題を 孕んでいる. この点について, ケア人材バンクは調査報 告として，「回答した介護職の $31 \%$ 『゙, 腰痛』, $54 \%$ が『腰痛になった経験がある』と答えている」ことをW EB上に発表していた.
同報告ではその原因で最も多いのが「ベッドからの移 動」, 次に「寝ている人の移動」であった. 介護職の誰も が行う行為であり,「介護職の腰痛は職業病とも言える」 とされるのは当然である. この現状を変えるため, 福祉 用具の利用が推奨されている. 出版されている関連書籍 には, 機器利用の説明を中心としたものが多いが, なお, 現状において，調査報告の実態がある.

この現状において, 小川鑛一ら ${ }^{11)}$ は, 英国の事例と して, 「過去 1 年以内に起こした腰痛という問いに対して, 1981 年の英国の調査では $43 \%$ でしたが，1995 年の調査 では $14 \%$ と少なくなっています. その理由は一人で患者 を持ち上げてはならないこと, 持ち上げに協力者が得ら れない場合はホイストのような持ち上げ支援補助機器を 使用寸る, 医療従事者の患者取り扱い講習会参加義務な どに関する規制が 1993 年に施行されたためと考えられ ます.」と述べている.

本論では,「職業病」といわれる介護職の腰痛の現状の 中で, この現状を改善する先進事例はある, との前提で,

「社会制度として，その先進事例はどのような筋骨格疾 病防止アプローチを行っているのか, 日本の現状はどう か, 福祉機器利用への意識はどうなっているか, 現場で はどのくらい介護者が，ベッドからの移動・寝ている人 の移動関連機器を利用しているか」を調査し, 先進事例 とわが国の現状の対比から，今後取るべき方策を明らか にし，その提示を試みる。

\section{2. 関連法律の概要}

\section{1. 労働法とは}

労働問題に関する法令全体の総称として使われている 労働法の基本理念は, 憲法第 25 条の生存権の保障, 第 27 条の勤労の権利と義務そして勤労条件の法定, そして 第 28 条の団結権, 団体交渉権, 団体行動権の労働三権の 保障にある. これを具体化した労働法は, 内容や目的に 応じて, 労働者の保護や労使関係の安定のために定めら れている. その成立の端緒は, 労働条件の最低基準を定 める労働者保護のための法規とされる. その後, 雇用関 係法(個別的労働関係法), 労働者の団結権等の保障に関 する労使関係法(集団的労働関係法)が生みだされた.

企業サイドから見ると, 現在の経済グローバル化に伴 い, 法令遵守 (コンプライアンス), 労衝安全衛生への対 応，人権への配慮，環境対策などの取り組みの強化は， 日本国内のみならず, 諸外国における活動においても全 ての企業に必須であり, その対応が不十分である場合に は市場からの撤退を余儀なくされることもあり, 組織的 な対応が必要であると共に行われている.

労働法を各国横断的に俯瞰すると, 米国の労働法は, 他の先進諸国と比べると，どちらかといえば「会社志向」 
でほほとんどの州では，従業員の雇用を「随意雇用」 (at-will employment) としている. さまざまな保護法 により, 会社による搾取から充分に守られているものの, 基本的な労働関連法規は, 従業員よりも経営側を優遇し ている傾向が特徵である. また労働安全衛生(HSE:Health and Safety, Environment）に関する法規制は各国によっ て大いに異なっているといえる.

労働条件に対する第三回ヨーロッパ意識調査 2000 年 12) では, 筋骨格疾病の減少について, 「英国労働者の 25. 3\%が，仕事が背中の痛みという形で健康に影響を受 けた」と報告された. これは最も高い割合を持つ 2 力国 であるギリシャの $42.1 \%$, フィンランドの $39.6 \%$ とは顕 著な差異がある. 又EU全体の平均は $31.7 \%$ であった. 福 祉先進国が多いEU域内で唯一英国よりも低い数值を示す 国は，アイルランドであった．英国は福祉先進国とされ る北欧諸国に比してもより顕著な筋骨格疾病減少を実現 した.

英国 $^{13)}$ ，米国 ${ }^{14)}$ ，オーストラリア15) の特徵はそれぞれ の国の看護師の報告にも現れている.

\section{2. 労働法に関する考察}

我が国における労働問題に関する法令全体の中で,「労 働基準法, 労働組合法, 労働関係調整法」を労働 3 法と 呼び，基礎となっているが，加えて本論に関連する可能 性がある労働環境等を定めた法律として, 労働安全衛生 法がある、その第二条では，この法律において，労働災 害を「労働者の就業に係る建設物, 設備, 原材料, ガス, 蒸気, 粉じん等により, 又は作業行動その他業務に起因 して，労働者が負傷し，疾病にかかり，又は死亡するこ とをいう.」と定めている. さらに労衝衛生に関連する 法規として, 作業環境測定法, 労働関係調整法, じん肺 法, 労働災害防止団体法, 労働者災害補償保険法などが ある、職業安定法も有名な法律である。また，労働を表 題に持つ法律は, 「労働者派遣法」,「介護労働者法」,「個 別労働関係紛争解決促進法」,「中小企業労働力確保法」,

「パート労働法」などがある.

労働基準法は十三章からなり，女子労働基準規則が, 「労働基準法 (昭和二十二年法律第四十九号) 第六十四 条の二第二項 及び第四項, 第六十四条の三第一項第二号, 第四号 及び第五号, 第六十四条の四, 第六十四条の五第 三項 並びに第百十五条の規定に基づき,並びに同法を実 施するため, 女子労働基準規則を次のように定める.」と して設けられている.

（1）省令による介護・看護労働の位置付け

この規則では，「第二条一 次の表の上欄に掲げる年 齢の区分に応じ，それぞれ同表の下欄に掲げる重量以上 の重量物を取り扱う業務」と定め, その内容を Table 1 に纒めている。
しかし, 以下のとおり, 臨時の必要のため坑内で行わ れる業務等が第一条の一 医師の業務, 二 看護師の 業務で定められている.さらに介護などの家庭内労働は, 労働とはみなされず，除外対象になっている.

労働基準法第六十四条の二「ただし, 臨時の必要のた め坑内で行われる業務で厚生労働省令で定めるものに従 事する者（次条第一項に規定する妊産婦で厚生労働省令 で定めるものを除く.）については，この限りでない.」

Table 1 危険有害業務への就業制限等

\begin{tabular}{|l|l|l|}
\hline \multirow{2}{*}{ 年齢 } & \multicolumn{2}{|c|}{ 重量 (単位 キログラム) } \\
\cline { 2 - 3 } & $\begin{array}{l}\text { 断続作業の } \\
\text { 場合 }\end{array}$ & $\begin{array}{l}\text { 継続作業の } \\
\text { 場合 }\end{array}$ \\
\hline 満十六歳未満 & 十二 & 八 \\
\hline $\begin{array}{l}\text { 満十六歳以上満十八歳 } \\
\text { 未満 }\end{array}$ & 二十五 & 十五 \\
\hline 満十八歳以上 & 三十 & 二十 \\
\hline
\end{tabular}

すなわち, 労働基準法には女性労働に際し, 重さに関 する基準(危険有害業務への就業制限等)があり，満 18 歳以上の女性で, 継続作業の場合 $20 \mathrm{Kg}$ 以上の重さの作業 が禁じられているが，医師，看護師の業務が除外されて いる.

また家内労働法（昭和四十五年五月十六日法律第六十 号）にも定めはなく, 家庭内家族労働が除外され, 女性 が多い介護者は家庭内労働でこの除外の中に含まれるこ とになり，法の規制外となっているのが現状である.

なお，関連する規則に労働基準法施行規則（昭和 22 年 8 月 30 日厚生省令第 23 号) がある.

\section{3. 英国における労働関連法の概要（six pack）}

1993年1月，英国に労働安全衛生に関する6法律が導入 された. これらの法律は，ヨーロッパ共同体（EC）の健 康と安全性に関する指令の必要条件を実践するために導 入された． ${ }^{16)}$ ヨーロッパ全体で共通の健康と安全性に関 する基準を構築することは，特定の参加国による不当な 競争を阻止するために「一つのヨーロッパ市場」を形成 する際の重要な一歩となる, と考えられている. さらに これら法律は健康と安全性が体系的に，そして整然と管 理されるように記述されている.こうした視点は自国の 統計書名に「ユーロスタット (EC統計局) からの結果」17) と記載していることからもうかがえる.

このことから, 本章1節で, 労働安全衛生に関する法規 制は各国によって大いに異なっていると述べたが，EUこ そが更なる健康と安全性に関する規則の発信源であり続 けると考えられるとの自負も見られる.

なお，これらの法律における必要条件の大半は新規の ものではなく, 議会報告 ${ }^{18)}$ が示すように 1974 年の「労働 安全衛生」法令で要求されていた事柄に関して, 責任あ 
る雇用者がどのように管理を行わ齐ばならないかをより 詳細に説明したものとされている.

以下その 6 法律とその要旨を示す.

Management of Health and Safety at Work Regulations 1992 (SI 1992 No 2051) ${ }^{19)}$

(健康と安全の管理に関する労働法)

この法律は，仕事をする全ての状況において，雇用者 がどのように効率的に健康と安全性を管理するべきであ るかを規定している. 全ての職場と全ての災害に適用さ れる重要法律である.

Manual Handling Operations Regulations ${ }^{20}$

(手作業業務に関する法律)

この法律は，持ち上げることと運ぶことの全ての業務 に関し, 雇用者が業務実施時の危険の削減を心がける際 に考慮しなくてはならない要因を規定している.

Health and Safety (Display Screen Equipment) Regulations 1992 (SI 1992 No 2792) 21)

(ディスプレイスクリーン装置の法律)

この法律は, 視覚的表示装置に関し, 装置と使用方法 からの危険の削減を雇用者に義務化している.

The Workplace (Health. Safety and Welfare) Regulations 1992 (SI 1992 No 3004) 22)

(仕事場「健康, 安全性と福利」の法律)

この法律は，仕事場で広範囲の健康と安全と身体保護 問題の基本的な標準を規定している.

The Provision and Use of Work Equipment Regulations 1992 (SI 1992 No 2932) 23)

(準備と使用に関する業務用装置の法律)

この法律は, 雇用者が正しい装置を選択し, 健全で安 全な方法でそれが使われることを確認する責任を規定し ている.

The Personal Protective Equipment at Work Regulations 1992 (No. 2966) ${ }^{24)}$

(個人の保護を目的とする装置の法律)

この法律は，危険をコントロールする他のどのような 方法もないと確認できる適切な保護装置の選択と，その 装置の適切な使用と使用の維持を確認することを, 雇用 者に義務化している.

本論に関連する法律は, Manual Handling Operations Regulations 1992 (手作業業務に関する法律) である.

\section{4. 健康と安全の管理に関する労働法}

全ての職場と全ての災害に適用される重要法律であり, この法律において, 雇用者は自らの従業員, 又はその他 の人間への全ての重大な危険を査定しなければならない とされる. また， 5 人以上の従業員を有する場合は查定 記録を保管しておかなければならず，その査定は予防措 置として, 又は保護目的のための指標も危険性を制御す
るために特定する必要がある. 雇用者は, 女性や子供の 健康を保障し, 若年層に特徵的な経験不足や潜在的危険 性の自覚の欠如，そして未熟さを考慮に入れながら危険 性を查定しなくてはならないとされている. 有給休腵の 規定もこの法律である.

わが国の労働基準法前述部や労働安全衛生法に該当す るといえるが, 雇用者は, 効果的な健康と安全性に関す る計画, 組織, 規制, 整備, 検査の方策を立てるべきで あるとされ, さらに, 必要に応じてこれらの方策は労働 者の健康監視システムを含む必要があるとされている.

\section{（1） 法律の条文抜粋記述}

1999 年, 健康と安全に関する法律第 3242 号, 「労働に おける健康と安全の管理に関する法律１999」は同年 12 月 3 日に改定案が起草され, 12 月 8 日に議会提出, 12 月 29 日に発効した.

法律の条文は 30 章からなっており, 以下に示す.

(1)告知, 発布と解説, (2)法の適用除外について, (3)危険 查定, (4)適用される予防原則, (5)健康と安全の取り決め, (6)健康監視，(7)健康と安全の支援， 8)重大か差し 迫った危険のため，また危険区域のための手順，(9)外部 のサービスとの関連, 10従業員のための情報, 11協力と 調整, (12)雇用者下での労働者又は自営業者の仕事, 13能 力と訓練, (14従業員の責務, (1)臨時雇いの労働者, 16乳 児を持つ母親又は妊婦に関する危険査定，17乳児を持つ 母親又は妊婦に関する登録開業医の証明書, (18乳巟を持 つ母親又は娃婦による通知，(19若年者の保護，(20)除外証 明，2責任に関する条項，22民事責任の除外， 23英国外 における法律の適応，41981 年の健康と安全 (応急手当) 法の改正, 251989 年の沖合設備とパイプライン (応急処 置) 作業法の改正, 261995 年の多岐に渡る健康と安全に 関する対策法の改正，11996 年の（健康，安全と福祉） 法律構造の改正，88健康と安全に関する法律として効力 を有するための法律, 29廃止と重大な改正，30暫定的な 準備

\section{5. 手作業業務に関する法律}

法律は 1992 年, 健康と安全に関する法律第 2793 号, 「手作業業務に関する法律 1992」として施行された. 手作業での荷物取り扱いに携わる労働者は非常に多く, 国家的に 3 日間以上休む必要がある全ての報告された傷 害の 3 分の 1 が, 手作業業務により起きている. しばし ば腰痛, ヘルニアや体の一部の損傷のような傷害は恒久 的な障害をもたらすことから，この法律への対応は多く の職場において重要とされている. 条文に示寸ように, 手作業で取り扱う「荷」はいかなる人や動物も含むとさ れ，介護・看護現場においても規制されている.

「手作業業務」は，「あらゆる輸送者，あるいは手や身 
体による荷の移動（荷の上げ下げ, 押し引き, 持ち運び などを含む)」と, 概括的に定義される. 介護者が要介護 者を移動する事も含まれている.

\section{(1) 実際的な例}

実際的な例は，HSEガイダンス ${ }^{25)}$ で与えられ，手作業 業務は「荷」を動か寸試みも含まれる，以下に述べる。

もし手作業で動かされている梁が落下して従業員の足 を折ったなら，それは手作業業務事故であり，もし梁が 不意図的に打ち倒され，類似の傷害を起こしたなら，こ れは手作業業務のためではない，また，扱われた荷から 出た有害物質あるいは腐食物による污染または漏出から 生じる障害のリスクなどは含まれない.

また道具あるいは標準的な目的のために使われている 機械は「荷」ではない，すなわち車から降ろされている チェーンソーは「荷」であるが，標準的な使用において は「荷」ではない。

法律は，全ての手作業業務に適用され，手あるいは身 体の力によって荷を輸送するか，あるいは支えることを 伴う業務に適用される。これは単に重い箱を持ち上げる などの明快な持ち上げ業務のみではなく, 調査業務, 詰 め込み業務，移動業務などにも適用する.

法律は最大の重量を定めていないが，雇用者は全ての リスク要因を考慮に入れなければならないとされる.

例えば, 荷の重量についてはEC 指令（条例6）で言及さ れているため, この法律においても同様に指摘されてい る. 荷重量は常に定められるわけではなく, トレーニン グを通じた安全な荷重量の取り扱いに関する十分な情報 の提供が求められる. さらにその準備は, 法の下で要求 され，効果的な傷害のリスクを軽減する他のステップも 除外してはならないとされている.

(2) 雇用者

雇用者は，一般的な規則として必要ではないが，複雑 な手作業業務などにおいて, 自身によるアセスメント(査 定）の実施を求められている. 雇用者には査定をする義 務があり，「従業員を自身で査定をするように訓練する」 ことによって，例えば，関係している従業員に查定業務 を委任することはできない．

雇用者の查定が，傷害の危険を減らすためにする段階 を追った訓練を含み，適切であると結論したとしても， 手作業業務は, 従業員がおそらく監督なしで安全に実行 できる範囲で実施できるようにするべく求められる.

\section{(3) 従業員}

従業員の義務は, 適切に提供された仕事のシステムに のみ及ぶ，仮に，雇用者が，法が規定する義務を果たさ ないなら, 従業員は仕事のシステムが「適切ではない」 といら理由から規定に従う必要がない. 事前に準備でき なかった緊急取り扱いなどの例のように，規定は善意か
ら生じた即席に作ったものに対する目安と見なしてはな らないとされている.従業員はこの法律 12 項で定める機 械と装置, 寸なわち手作業業務補助器具の使用に加えて, 雇用者によって与えられた訓練と指導のとおりの取り扱 いを義務とされている.

条文の翻訳を付録欄に記載する.

\section{6. その他の法律}

法律の存在を確認する作業について「ご指摘の規定を イギリスの法文から探すのは，大海で宝石を捜すような もので寸.」との中央大学法科大学院の山田省三教授によ るご注意もあり, 今後の研究者への指標として以下関連 法律を紹介寸る.

THE LIFTING OPERATIONS AND LIFTING EQUIPMENT REGULATIONS $1998{ }^{26)}$

Electricity at Work Regulations 1989 (SI 1989 No 635) 27)

Reporting of Injuries. Diseases and Dangerous Occurrences Regulations 1995 (SI 1995 No 3163) ${ }^{28)}$

The Health and Safety (Consultation with Employees) Regulations $1996{ }^{29)}$

The Health and Safety (Young Persons) Regulations 1997 (SI 1997 No 135) ${ }^{30)}$

\section{3. 英国における法律導入の社会的効果}

\section{1. 手作業業務に関する法律に基づく規制による社会 効果}

英国健康安全担当委員会 (HSE : Health \& Safety Executive）は統計ホームページを公開している. ${ }^{31)}$

調查当時, そこでは全国統計, データソース, 直面し ている問題, 健康と安全に関する目標や刊行物, 問い合 わせ電話番号などが確認でき，その内の「笳骨格疾病 (Musculoskeletal disorders) 報告書」には, 手作業業 務法施行以前の 1990 年〜 1991 年から 2002 年〜 2003 年の 間の改善の度合いが報告されており, Fig 1 に示す通り 法律公布時の 1992 年 1993 年で最も多く, 以後暫減し ている様子が明瞭に示されている.

また，「自己申告による仕事関連の疾病報告」(SWI） ${ }^{32)}$ によれば，筋骨格疾病のためとして傷害補償のために新 たに査定されたケースの数は 1992 年〜1993 年において ピークであり，以後は一部変動があるものの 2002 年〜 2003 年まで毎年減少し続けているとしている. なおこの 間の調査では小川鑛一ら ${ }^{11)}$ の言う, 「過去 1 年以内に起 こした腰痛という問いに対して, 1981 年の英国の調査で は 43\%でしたが, 1995 年の調査では $14 \%$ と少なくなっ ています.」は確認できなかった. 


\section{Figure 1: Musculosketetal (mainly upper limb) Disorders}

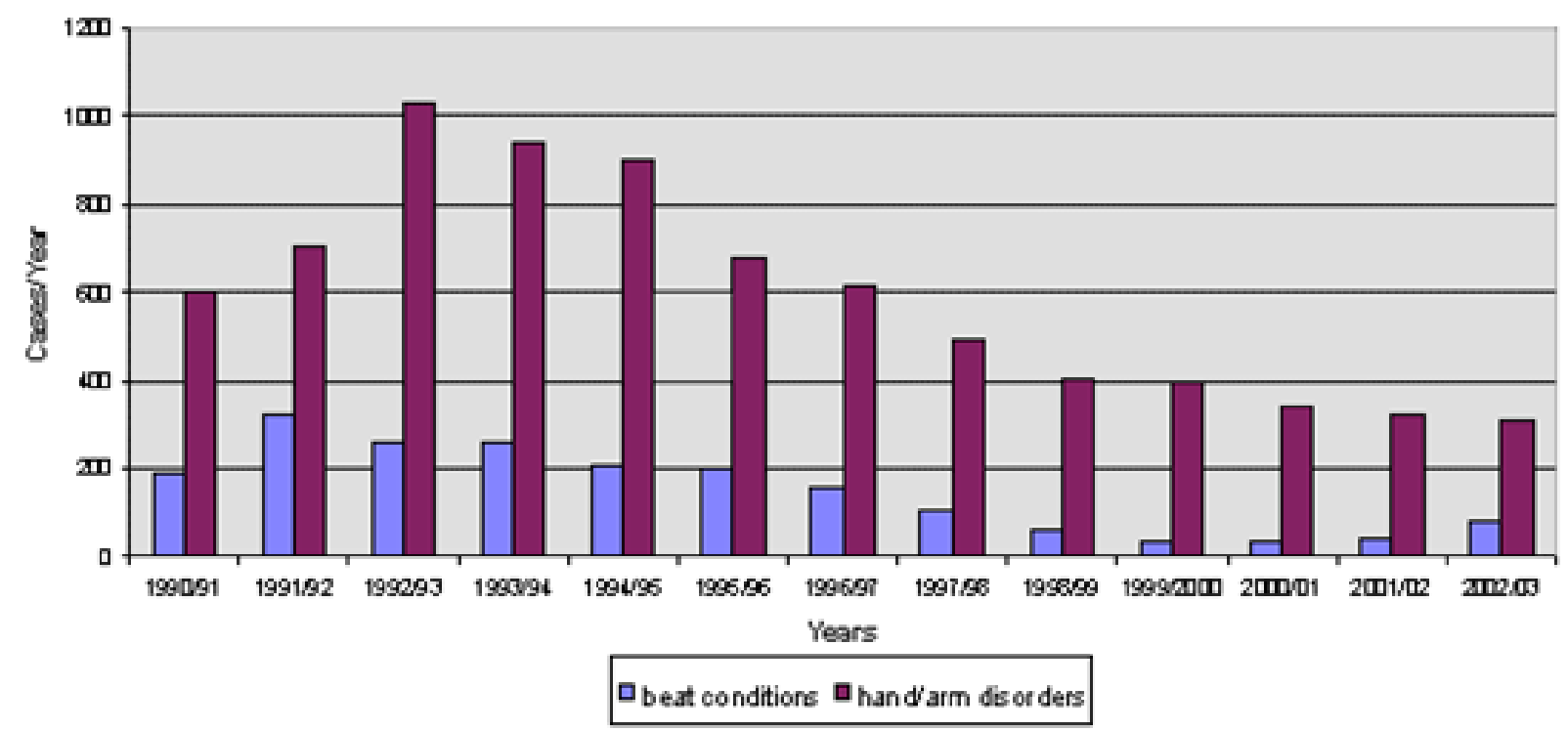

Fig 1 手作業業務法施行以前の 1990 年〜 1991 年から 2002 年の間の改善 (出典 : HSE - STATISTICS: Musculoskeletal disorders)

\section{（1）筋骨格疾病についての報告}

「自己申告による仕事関連の疾病調査」(SWI03/04)の 結果では, 2003 年〜2004 年時点ではおよそ 110 万 8 千人 の人々が過去の，または現在の仕事によって何らかの筋 骨格疾病が引き起こされた, 又は悪化したという結果が 出ている. これは, 10 万人中 2,600 人, 英国での労働経 験者全体の $2.6 \%$ に一致する.

過去 12 ケ月の間にイングランドとウェールズで働い た人は，限られた範囲に準拠して実施された 5 回に渡る SWI 調査と比較してみると，2003 年〜2004 年の結果は 2001 年〜2002 年の結果と類似しているが, 1998年〜1999 年の結果よりは高く, また 1990 年と 1995 年の結果より は低くなっている，これら全ての偏差には統計的有意差 が認められる.

SWI03/04 の報告では，患者の 18\%，すなわち雇用経験 のある 20 万 4 千人は, 当初彼らの仕事に起因寸る筋骨格 疾病に気づいたのが過去 12 ケ月中であったと概算して いる. 過去 12 ヶ月間に雇用された人々に関しては, 10 万分の $640 ， 0.64 \%$ の発生率とみることがでさる. ${ }^{33)}$

毎年発生寸る, 筋骨格疾病の新しい何千ものケースは ある程度専門医の介入を必要としている. 2003 年には初 めてリウマチ専門医や医者に見せたというケースが約 5700 件あったとMOSS(筋骨格の業務監視計画） ${ }^{34)}$ と OPRA (作業療法士活動報告) ${ }^{35}$ ) に報告されている。毎年 約8000件発生していたそれまでの5年間に比較すると若 干低い結果となっている．この変化が筋骨格疾病発生の 実際の低下を反映しているかどうかを判断するには時期 尚早と言える.

2002 年〜2003 年においては，390 件が「自己申告によ
る仕事関連の疾病報告」で規定された筋骨格疾病による 傷害補償のために新たに査定された。 查定されたケース の数は 1992 年〜1993 年においてピークに達し，2000 年 〜2001 年において查定されるケースの数が前年より増 えたが，以後は 2002 年〜2003 年までそれ以来毎年減少 し続けている.

SWI01/02 に示される 2001 年〜2002 年において最も高 い有病率を示寸産業は，農業，狩猟，林業および釣り， 建設業, 健康・ソーシャルワークと製造業であり, そし て行政と防衛は平均以上の罹患率を示した. 又, 採鉱業 と採石業, 衣服製造業: 毛皮の着付けと染色業, 他の輸 送設備の製造業，および自動車両，トレーラ，およびセ ミトレーラの製造業は2001年と 2003 年の間でMOSSにリ ウマチ専門医から報告された最も高い年間平均の有病率 を持つ産業の一部であった。

SWI03/04 は, 2003 年〜2004 年において 1180 万日（全 日としての量) が仕事に起因する，又はそれによってよ り悪くなった筋骨格疾病によって浪費されたと概算した. 平均して, 各患者はその 12 ヶ月で約 19.4 日の休みを取 った. これは年 10 万人の労衝者に換算し 5 万 2 千日を 年平均で失ったことと同等である.

（2）法律による介護機器の導入

「1998 年の英国における背痛患者の数」冊子吕) によれ ば, 1999 年に国内全ての病棟に, リフトとスライドシー トが配備された. これは前出の持上げ操作と持上げリフ 卜の法律 199826) による配備である. その効果についての 言及は見当たらないが, NHSのグラスゴー地域によるケー ススタディ ${ }^{37)}$ がその導入について報告している. 


\section{2. 背痛の社会的影響}

（1） NHS 報告に見る背痛の社会的影響

NHS（英国国立保健局） ${ }^{38)}$ は，支払う能力ではなく， 必要に基づいて，全ての市民に医療を提供寸るために 1948 年 7 月 5 日に設立された。 このNHSのマネージャー ズガイド39) は「報告された全ての事故による傷害の 3 分 の1が, 手作業業務事故によっています. NHS手作業業務 事故報告書によると, 病欠の 40 パーセントが手作業業務 事故に起因しています。そのNHS へのコストは各年 4 億 ポンドに及んでいます。 そして意欲的で，生産的な人々 が手作業業務事故と関係がある痛みと障害のために仕事 を断念してきました.」とし，125 万ポンドの支払いを指 摘している.

手作業業務事故に対寸る危機感をもつNHSでは, 「The Back in Work campaign」40) を行っている. そのキャン ペーンで, 標語は「手作業業務を避けてください」であ り, 「病院で療養院あるいは共同体養老院では, 手作業で 患者を持ち上げるとき, 誰でも安全性を危険にさらすこ とになります. 介護リフト, 滑動補助器と他の専門的な 装置の利用が, 仕事中のスタッフのけがの危険をなくす ことを意味します.手作業の持ち上げが NHS スタッフの 健康に関してその犠牲を強い続けます.」としている.

（2） HSE 報告に見る背痛の社会的影響

HSE（健康と安全実行委員会）は，英国における事業 活動から生ずる健康と安全に対する危険に関する法律の ほとんど全てに責任を持っており，背骨の障害について WEB「Better Backs, About back pain」41) を公開し, 背 痛について原因, 解決のための課題, 受傷による経済的 損失が述べられており，そこでは「英国で 220 万人が 2003/04 年に労災で苦しみ, 5 件の内 1 件が背部の障害に 起因し, およそ 5 百万仕事日が 2003/04 年に背部の障害 で失われた」としている.

例として,「失業したままでいるバーミンガムからのジ ヨン」をあげ，「彼が基本的な規則を忘れたから，慢性の 背中の痛みで長期の失業している犠牲者」と述べている.

（3） TSSA 報告に見る背痛の社会的影響

輸送業・旅行業に従事する人々のための 1897 年に設立 されたTSSA（輸送労働者労働組合: 33,000 人）は, 今日 まで何年もの間, 背中の痛みが全産業で従業員の病欠の 最も普通の理由の 1 つであるとして, 背中の痛みに関す るキャンペーン42)を行っており, NHS報告を引用して, 仕事日 1 億 8000 万日が失われたことをあげて警告してい る.

\section{3. 英国の法律施行に関する諸報告}

（1）地方自治体の報告 (HELA)

HSE $と$ the Health and Safety Executive/Local Authority Enforcement Liaison Committee（地方自治体
連絡委員会: HELA) は, 年報を発行している. 年報のHELA ANUAL REPORT $2003{ }^{43)}$ 及びHELA SUPPLEMENTARY REPORT $2003^{44)}$ 地方自治体が実施した健康と安全不法行為者と 罪と罰実施報告である. このレポートには 2002 年 4 月 1 日と 2003 年 3 月 31 日の間に有罪を宜告された全ての健 康と安全不法行為者のリストが報告されている. この報 告書は, 安全不法行為者と罰のリストを公開するもので あり, HSEの地方自治体ユニット (LAU) に, 単に違法の ケースだけが地方自治体によって通知されるのを記録し たものである.リストには地方自治体による告訴中のも のも含まれる. HELA 2003 年の年次報告書と付属書を補 っている.

内容は，健康と安全不法行為者リストとこの報告の罰 則は, 2002/03 年の間の有罪とされた任務保有者の罪状 の細部を明らかにするとともに, 法廷によって課された 罰金額を示している. 仕事中に, あるいは仕事場で健康 と安全に関連している374の有罪決定が98の地方自治体 によって報告された．そこには 7 つ消防局や郡議会よ る 62 人の不法行為者が含まれる. 平均の罰金は 3676 ポ ンドであった.

（2）查定実施に向けた取り組み

手作業業務に関する法律が査定を要求し, 定型の定め がないため, 公共団体も含め各企業はそれぞれ対応マニ ユアルを策定し，責任者を置いてその実施に責任を持つ ことになる. HSE ${ }^{45)}$, 46) やNHS ${ }^{47)}$ そして地方自治体 ${ }^{48)}$, 49) か らマニュアルが提供されている. 提供されるマニュアル は自由に利用できる. 提供されたマニュアルを利用した 例は, 一般企業50), 51) や大学52，53)，54) に見られる. 1 冊が 無料である有料のガイド55) も発行されている.

この実施のため多くの研修実施を提供する企業が研修サ 一ビスや講習会56)，57），58）を提供している. また公共団体 も職場の健康と安全性のマネージメントに関し, 以下に 示寸利用可能な小冊子を発行している.

（3）リーフレット (Tendring 地区評議会環境保護サ ービス課) ${ }^{59)}$

手作業業務に関する実施要領では, 「手作業業務に関し， 雇用者の義務が示されている. 手作業の操作の定義も 2 章の通り示され，ここでは具体的に，オートメーション あるいは機械化の導入，フォークリフトトラックあるい は一輪手押し車の使用を含む可能性の指摘や，対象物を より小さいパッケージに分割することなどが示されてい る. 危険の查定も前項と同様に規定されている. 事例が 示されている.トレーニングの重要性が指摘されており, 従業員に周知すべき基本的な知識として, 以下が示され ている.
a）潜在的に有害な手作業業務を認識する方法.
b）手作業業務のために仕事の適切なシステム.
c）どのように，そしていつ機械的な手助けを使うべ 
きか。

d）良い取り扱いテクニック.

（4）有料講習会（機関による規定を定めるために） トレーニング会社のカタログ(0) $は$ は, 健康\&安全教育コ 一スと名づけられ，「応急手当のトレーニング専門家, 緊 急回答のトレーニング UK 社, 健康\&安全教育コース, 予防は治療より良い.」などの文面で宣伝に用いられてい る.

\section{4. 日本の状況}

2002 年 6 月 1 日 NHKは, 厚生労働省による腰痛·頸 肩腕障害などに関わる調査開始に関する報道を行った。

「仕事で重い腰痛になった人は毎年 5000 人前後で労働 災害と認定された病気の半数を占めています. 有効な予 防策や治療法を検討するため全国 39 の労災病院が共同 で初めて腰痛と労働環境などの大規模調查を行うことに なりました.」と報じた. 労災としての腰痛が, はじめて 政策課題になったともいえる.

以下に現状の調査報告を纒めた。

\section{1. 介護 · 看護労働における被介護者の移動に関する意 識の質問紙調査 ${ }^{61)}$}

2001 年に中小企業総合事業団助成による『創動運動用 上肢訓練器兼用リフト機器開発に関する研究調査』を実 施した. 東京都, 大阪府, 愛知県及び京都府に所在する 指定介護老人福祉施設 (特別養護老人ホーム), 介護老人 保健施設, 訪問看護ステーション及び指定介護療養型医 療施設 (寝たきり老人病院) の 2000 施設に, アンケート 用紙を同年 10 月 1 日より 15 日の間に送付した. 回収総 数は 120 通，回収率は $6 \%$ であった. Fig 2 に, 質問紙調 査に対する回答を纏めた。

\section{1. リフトを利用していますか \\ 2.将来在宅で利用すると考えますか 3.上肢訓練機を日常的な訓練用 具として利用していますか 4.将来在宅で利用寸ると考えますか}

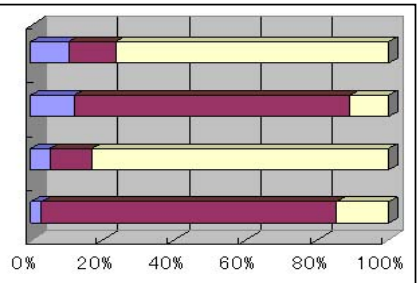

\begin{tabular}{|c|c|c|c|c|}
\hline & $\begin{array}{l}\text { リフトを利用 } \\
\text { しています } \\
\text { か }\end{array}$ & $\begin{array}{l}\text { 将来在宅で } \\
\text { 利用すると考 } \\
\text { えますか }\end{array}$ & $\begin{array}{l}\text { 上肢訓練機 } \\
\text { を日常的な } \\
\text { 訓練用具とし } \\
\text { て利用して } \\
\text { いますか }\end{array}$ & $\begin{array}{l}\text { 将来在宅で } \\
\text { 利用すると考 } \\
\text { えますか }\end{array}$ \\
\hline はい & 8 & 9 & 4 & 2 \\
\hline $\begin{array}{l}\text { どちらとも } \\
\text { いえない }\end{array}$ & 10 & 57 & 9 & 56 \\
\hline いいえ & 58 & 8 & 64 & 10 \\
\hline
\end{tabular}

Fig 2 質問紙調査結果(1)
(1) 質問紙調査結果からの考察

「1.リフトを利用していますか」に対する利用してい ない「右側・明色の否定回答」は「76.3\%」に上る.「2. 将来在宅で利用寸ると考えますか」に対する利用しない 「否定回答」は「10.8\%」に減少寸る. そして「どちら ともいえないとする「中央・中間色の留保回答」が「77\%」 に増加する。「3.上肢訓練機を利用していますか小に対す る利用していない「右側・明色の否定回答」は「83.1\%」 に上る.「4. 将来在宅で利用すると考えますか小に対する 利用していない「否定回答」は「14.7\%」に減少する。 そして「どちらともいえない」とする「中央・中間色の 留保回答」が「80.6\%」に増加する。

（2）国際福祉機器展におけるアンケート調査と考察 法制化の可否を調査するため, 労働基淮法規定に特化 したアンケート調査を 2001 年国際福祉機器展において, 東京電機大学の学生の協力を得て, 実施した. ${ }^{61)}$

展示期間中にアンケート回答を得た対象者は前記助成 研究に興味を持ち展示ブースを訪問された各層からなる 無差別な回答者であり, リフト機器開発に興味を持つ任 意の参加者である，その中で，労働基準法で利用を決め られていたら利用する者はFig 3 に示寸有効回答 15 票中 12 票であり，80\%の高率である. 法による規制の有用性 を示唆している.

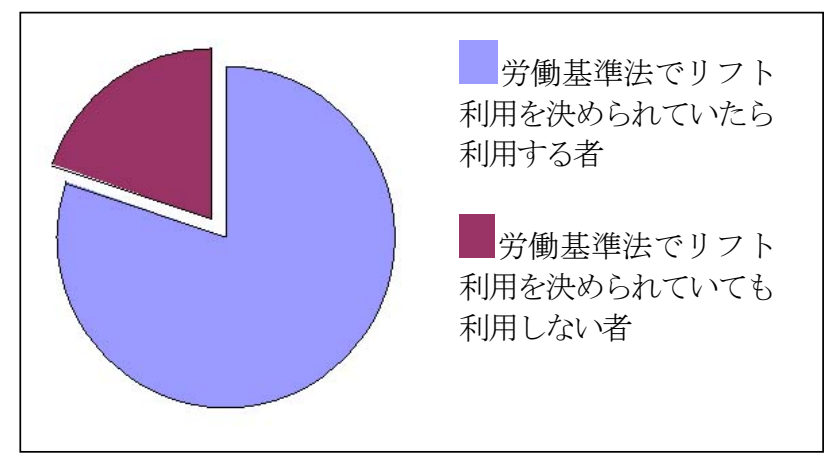

Fig 3 国際福祉機器展におけるアンケート調査結果

\section{2. 腰痛対策を視点に論文調查}

（1） 大阪府における調查の概要 (高齢者介護施設など の職員の腰痛·頸肩腕障害などに関わる質問紙調 查) ${ }^{62)}$

大阪府立公衆衛生研究所 労衝衛生部が実施した大阪 府における高齢者介護施設などの職員の腰痛·頸肩腕障 害などに関わる質問紙調査では, 全回答者（訪問介護従 事者) 486 名 (平均 48.3 歳, $S D=10.8$ ) のうち女性が 471 名 $(96.9 \%)$ で平均年齢は 48.7 歳, $\mathrm{SD}=10.5$ であった. 女性では 50 歳代が最も多く, パートタイマーが $60 \%$ 正 規職員 $16 \%$ ，常勤的非常勤 $12 \%$ であった「腰が痛い」 の訴え率は, 正規職員で「毎日のように」33.8\%と「週 
1 2 回」36.5\%を併せて $70.3 \%$, 常勤的非常勤では $58.6 \%$ ，パートタイマーでは 58.6\%であった.

常勤職員では 70\%異常, 非常勤職員でも $60 \%$ 程度が腰 痛を訴え, 介護施設従事者と訪問介護従事者共に腰痛の 訴えが高いことが明らかになった。

この改善のために, 次の対策を挙げている.

腰痛防止には特効薬的なものはなく, 総合的な対策が 必要である. 介護機器の導入 : 各施設の事情に合わせて 活用できるようによく検討してから導入する. 腰痛職場 であることの認識. 作業基準の周知・実行方法・始業前 体操・腰痛体操の導入・防護具（腰部保護ベルト）の紹 介と効果の周知 : 効果的な使用には指導が必要. 腰痛検 診 (特殊検診).

*職員が実行すること

始業前ストレッチ. 筋力強化 (腰痛体操). 防護具 (腰 部保護ベルト）の着用（着用により腰部筋肉負担が軽減 される.), 悪い作業姿勢を知って避けること.

以上から, 腰痛防止には特効薬的なものはなく, 総合 的な対策が必要であるとしているものの, 介護機器の導 入においても，各施設の事情に合わせて活用できるよう によく検討してから導入するなどとしており, 法改正に よる, 重量物すなわち被介護者の移動・移乗介助の規制 と実施の介護機器利用を含めたマニュアル化といった根 本的な改善策を導入する要素は見られない.

（2）その他の視点からの調查 : 腰痛対策について

山本ら ${ }^{63)}$ は, 不自然な作業姿勢が職業性腰痛の発生に 関与するとして, 調査し, 立位前屈作業による腰痛の出 現率が高く, 作業管理上の問題点として指摘している.

市堰ら ${ }^{64)}$ は, 事務作業でかえって腰痛の多いことなど ストレス社会の現状を反映して, 腰痛対策がますます複 雑化してきているとしてメンタルヘルス要因が重要にな るとして調査を行った. その結果身体健康度の方が腰痛 と強く関連していると述べている.

小森ら ${ }^{65)}$ は「職業病としての腰痛は, 今日の職場や作 業現場でよくみられ，作業管理の面から腰痛に対してそ の疫学や, 行われている治療・予防について, 法制化, 経済的理由，やむを得ないもの（無理な姿勢を取らない といけない作業）等が考えられ，対策は治療と予防であ る.」と述べている. 以上の研究から, 立位前屈という誰 もが取りそうな姿勢や, 作業時の不自然な姿勢, 腰に負 担のかかる重いものを持つ, などで腰痛を招き，「根本的 な原因として, 生物学的に人間は 2 足歩行のため腰痛に なりやすい」とはっきりと腰痛を防ぐことが困難である ことを述べている.

腰痛による経済的損失に触れている論文も見受けられ るが，実施されている厚生労働省の大規模調查が明らか にする結果が明確な数字を出すであろうと期待している ところである.

\section{3. 福祉用具利用の現状調查}

（1）福祉用具産業の市場規模調查から見る介護リ フトの現状

介護機器の導入に関し考察する視点で介護リフトの市 場における需要の現状を, (財) 日本システム開発研究所 が実施した日本福祉用具・生活支援用具協会委託事業の 報告66) から調查した. 2004 年度の福祉用具産業の市場規 模推計を, 従来の経済産業省が公表してきた市場規模推 計調査の手法により, 調査し報告している.

その概要に寄れば，リフトは 2004 年度 18 億円の市場 規模で, 減少傾向とされている. 現在市場に出回ってい る代表的な既存のリフトを形態・動作メカニズムなどか ら分類し, 類型化すると床走行リフト吊り下げ型, 天井 走行型リフトなど移乗・移動方法に違いが見られる.

「2003 年度の福祉用具 (狭義) の市場規模は, 市場規 模は全体で 1 兆 1,786 億円と, 対前年比約 $0.3 \%$ の現象 となった. 2000 年度に対前年比マイナス成長となったが, 2001 年度には増加に転じ, 2002 年度の市場規模は対前年 に比べ漸増したものの, 2003 年度は再び前年比マイナス に転じた.」とされた. また介護保険制度により，レンタ ル品目に限れば市場規模及び品目数漸減傾向が顕著であ るとされている. さらに, 現在, 市場に供給されている リフトへのニーズは，技術的・機能的な面よりもコスト 面であり, さらには, 日本家屋独特の特性とリフトのマ ッチングなどもケース毎に異なるなど,「使いやすさ」へ のさらなる希求への対応も進んでいないといわれている.

(2) 福祉機器利用に関する利用者の意識

東京大学整形外科を主管とする治験でソリ付き歩行器 の利用により, 大腿骨頸部骨折患者が何人も歩行自立を 果たした. ${ }^{67)}$ 介護保険の利用も可能で, 誰でも利用でき るが, 普及しない. 2005 年の医師への聞き取り調査 ${ }^{68)}$ に よると,「患者さんが歩行器を利用寸れば歩ける, そう思 って診断書に書いた. すると家族から『先生の診断書の おかげで，民間の寝たきり保険の保険金が得られなかっ た. 生活設計が狂った.』と言われた.」の実際がある

施設で言えば介護度が深刻になるほど介護報酬が高い。 安全管理の面からも監視が必要な状態での歩行は望まれ ない. 器具の利用が利用対象者からも, 介護者からも望 まれない現状のようである. 福祉用具利用に法整備の必 要性を他の一面で示唆していると思われる。

\section{5. 問題点と今後の課題}

\section{1. 問題の所在}

本論は今後の高齢者と高齢障害者の増加による社会崩 壊の危険を少しでも軽減する目的を持つ. 高齢者介護が 国民生活全体に大きな影響を与えることは社会の少子高 齢化伸展からも明らかである. 介護は人と人との間での 
行為であり, 特に在宅介護に入るへルパーの 8 割が腰痛 に悩まされている現状があるにもかかわらず，介護する 側, 特に介護者の健康管理については見失われがちだっ た. 老々介護の状況を思いやることからも, 介護者の健 康管理は, 介護サービスの質的向上や量的拡大と不可分 といえる.

英国は福祉先進国が多い EU 域内で, 福祉先進国とさ れる北欧諸国に比してもより顕著な筋骨格疾病減少を実 現した. これは手作業業務に関する法律の導入によると される. この事実を範に, 筋骨格疾病減少に関し, 我が 国においても同様な効果を実現するため, 現在の状況と 法整備とその執行について, わが国との対比研究を行っ た.

筋骨格疾病减少に必要な法律を調查し, その執行の現 状を明らかにした，同時にわが国の法整備と執行の現状 を調査し，その相違を明らかにした。 わが国の筋骨格疾 病減少へ向けた看護・介護現場における意識, 減少させ るための対策やその現状を調査し, 明らかにした.

\section{2. 研究結果}

第 3 章に述べた, 英国の「筋骨格疾病 (Musculoskeletal disorders）報告書」には, 手作業業務に関寸る法施行以 前の 1990 年〜1991 年から 2002 年〜2003 年の間の改善の 度合いが報告されており，法律公布時の 1992 年〜1993 年で最も多く, 以後暫减し, その 3 割にまで減少した様 子が明瞭に示されている.

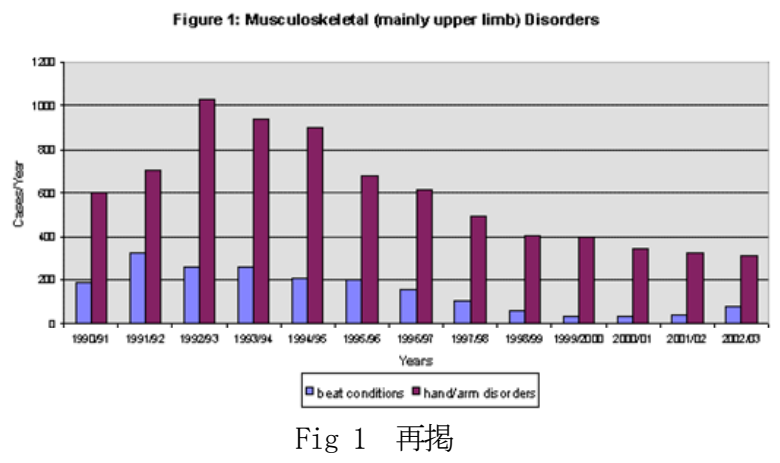

英国との対比から，現状の法体系のままでは，わが国 における看護・介護現場の筋骨格疾病減少は期待できな いことが分かり，採るべき対策として，法整備の必要性 を明らかにした。

第 4 章に明らかにした調查結果から,わが国において, 現在根本的な解決策は見当たらず, 筋骨格疾病減少は法 整備により実現すべきであることが分かった.

法制定により，手作業業務に対する削減計画の策定， 研修を通じた意識向上, 保険者による機器利用の推進, 機器利用による業務代替や実施の安全姿勢の確保を行い, 看護・介護労働現場での労災（腰痛など筋骨格疾病）を 減らす事が可能になる.

\section{3. 具体的提案一取るべき法整備—}

具体的には，労働基潐法を遵守することが必要で，女 性労働基淮規則 (昭和 61 年 1 月 27 日労働省令第 3 号) のうちの, 労㗢基準法第六十四条の二「ただし，臨時の 必要のため坑内で行われる業務で厚生労働省令で定める ものに従事する者（次条第一項に規定する妊産婦で厚生 労働省令で定めるものを除く.) については, この限りで ない.」とし, 満十八歳以上の女性の作業重量を断続作業 の場合 $30 \mathrm{~kg}$ 以下, 継続作業の場合 $20 \mathrm{k} \mathrm{g}$ 以下と定めて いるが，例外規定として，医師の業務，看護師の業務を 定めている. この重量物持ち上げに関する除外事項を削 除する必要がある.

家内労働法にも定めはなく, 家庭内家族労働が除外さ れ, 女性が多い介護者は家庭内労働でこの除外の中に含 まれることになり, 法の規制外となっている. これを規 制する必要がある. また男女平等の面からすると, 男性 に対する基準も必要と思える. その場合に, 取り扱い可 能な重量の個人差についての問題もあり, 特定の重量を 定めずガイドラインを定め, 柔軟な個別対応を可能とし ながらも結果責任を問う, 英国の「手作業業務に関する 法律」に類する法律の導入も検討されるべきである.

持上げ用機器の整備と利用を，責任を負う者に課す場 合, 責任を負う個人・企業・団体ばかりでなく, 国民健 康保険などの公的健康保険や民間事業者で組織される健 康保険組合などの保険者の保険給付と, 法律遵守に向け た器具の設置責任義務の関係も明確にすべきであろう。 その上で, 家庭内労働や手作業業務が見えないところで 実施される一面があり, 法律遵守の誘導手法も, 本論 3 章 3 項で明らかにした手法の導入も検討されるべきであ ろう.

さらに英国では機器利用に法整備がされている. 持上 げ機器が全ての病棟に準備されている状況は, 保険者に とって筋骨格疾病が与える保険会計一の経済的影響と機 器の準備コストの対比を含め, 介護現場の必要が反映さ れた結果であろう。導入結果を明確に述べることができ ない現状では, 機器利用に向けた法規制を直ちに主張す ることはできない. しかし, 労災の発生とそのための給 付を検討した場合, 歩行器の例の考察からも機器利用の 促進を保険者の責任に取り入れる必要があり, 何らかの 法整備が必要と考察する.

\section{4. 法の実効性の為に-- 英国社会の重量物取り扱いから の提案 -}

第 3 章に述べた HELA SUPPLEVENTARY REPORT 2003 (健 康と安全不法行為者と罰・活動分野 A 報告) の報告書は, 安全不法行為者と罰のリストを公開している. その内容 は, 有罪とされた任務保有者の罪状の細部を報告すると ともに，法廷によって課された罰金を示している．仕事 
中に，あるいは仕事場で健康と安全に関連している 374 の有罪決定が 98 の地方自治体によって報告され, 公開さ れているのである. そこには自らの責任部署である $7 つ$ の消防局や郡議会よる 62 人の不法行為者が含まれてお り, その公平性を担保している. 平均の罰金は 3676 ポン ドであり, EU 域内で祭立って高い筋骨格疾病減少の実績 を保つための代償と理解できる.

看護・介護労働現場での腰痛など筋骨格疾病を減らす ために，新たな規制もやむをえないものとし，国民の合 意を図る必要がある，その合意により，在宅における介 護が充実するのであれば，持続可能な高齢社会構築に大 きな一歩となると考察する.

\section{参考文献}

1) 内田健司 (2001. 1.24) 「半世紀後の日本人の寿命 93 歳」『読 売新聞』

2) 平成 18 年版「高齢社会白書」

3) 三重県(2003.05)「第 3 次三重県高齢者保健福祉計画・第 2 期三重県介護保険事業支援計画（素案）」

4) 保険毎日新聞（2004.8.13）『保険毎日新聞』

5）平成 17 年版厚生労働白書

6）共同通信 (2005.6.8) 『共同通信』

7）国税庁（平成 17 年 10 月 12 日）『平成 16 年度民間給与実態 統計調查の概要』

8）日本経済新聞（２005.4.14）『日本経済新聞』

9）望月涁也（2004.9. 30）「連載コラム 在宅介護と福祉用具 〈1〉」日本労働者協同組合センター事業団

http://fksyuu. roukyou. gr. jp/coramu/2004. 5. htm

10）読売新聞 (2004.8.22)『読売新聞』

11）小川鑛一，他（2003.1）「看護動作のエビデンス」東京電機 大学出版局

12) Third European Survey on Working Conditions 2000European Foundation for the Improvement of Living and Working Conditions 2001

13) Love, C. Lifting injury, (1997) a study of the occupational health perspective, Nursing Standard, 11, 26, 33-38,

14) Castro, A. B. PhD, MSN, MPH, RN, (September 30, 2004) HANDLE WITH CARE, THE AMERICAN NURSES ASSOCIATION CAMPAIGN TO ADDRESS WORK-RELATED MUSCULOSKELETAL DISORDERS. Online Journal of Issues in Nursing Article

15) HEALTH \& COMMUNITY SERVICES INDUSTRY REFERENCE GROUP, (2001.11), Utilization of the Manual Handling Competencies For Nurses', Heal th \& Community Services Organizations and Education Establishments in NSW. http://www. workcover. nsw. gov. au/NR/rdonlyres/96D88E C4-8909-46AD-A330-AFB290430068/0/report_hacs_mh_413 4. pdf.
16) Mansfield, J. N. (2002), PROPOSED EU PHYSICAL AGENTS DIRECTIVES ON NOISE AND VIBRATION, Department of Human Sciences, Loughborough University, Loughborough, Leicestershire.

http://www-staff. 1boro. ac. uk/ hunjm/abstracts/ergo2 002. pdf

17) J Jones, R. C. Huxtable, S. and Hodgson, J. T. (2001.5) Force Survey summer quarter, Self-reported work-related illness in 1998/99: Results from EUROSTAT i11-health module in the 1999, Labour, Health and Safety Executive (HSE).

18) Vidler, G. (20 APRIL 1998) Social and General Statistics Section (RESEARCH PAPER 1998/51), HOUSE OF COMMONS LIBRARY, Work Related Upper Limb Disorders

19) Management of Health and Safety at Work Regulations 1992 http://www. opsi.gov.uk/si/si1992/Uksi_19922051_en_1 .htm

20) Manual Handling Operations Regulations 1992 http://www. opsi.gov. uk/si/si1992/Uksi_19922793_en_1 .htm

21) Health and Safety (Display Screen Equipment) Regulations 1992 (51 1992 No 2792).

http://www. hse. gov. uk/lau/lacs/16-1. htm

22) The Workplace (Health. Safety and Welfare) Regulations 1992 (SI 1992 No 3004).

http://www. opsi.gov. uk/si/si1992/Uksi_19923004_en _. $1 . \mathrm{htm}$

23) The Provision and Use of Work Equipment Regulations 1992 (SI 1992 No 2932).

http://www. opsi. gov. uk/si/si1998/19982306. htm

24) The Personal Protective Equipment at Work Regulations 1992 (No. 2966).

http://www. opsi.gov. uk/si/si1992/Uksi_19922966_en_1 .htm

25 ) Health and Safety Executive / Local Authorities Enforcement Liaison Committee (HELA), (September 2000 ) Local Authority Circular, HSE and HELA. http://www. hse. gov. uk/lau/lacs/

26) THE LIFTING OPERATIONS AND LIFTING EQUIPMENT REGULATIONS 1998, HSE. http://www. hse. gov. uk/lau/lacs/90-4. htm

27) Electricity at Work Regulations 1989 (SI 1989 No 635). http://www. opsi.gov. uk/si/si1989/Uksi_19890635_en_1 .htm

28 ) Reporting of Injuries. Diseases and Dangerous Occurrences Regulations.

http://www. opsi.gov. uk/si/si1995/Uksi_19953163_en_1. htm

29) The Health and Safety (Consultation with Employees) 
Regulations 1996.

http://www. opsi.gov.uk/sr/sr1996/Nisr_19960511_en_4 .htm

30) The Health and Safety (Young Persons) Regulations 1997 (SI 1997 No 135).

http://www. opsi. gov. uk/si/si1997/97013501. htm

31) HSE Statistics

(http://www. hse. gov. uk/statistics/index. htm)

32) Jones, J. R. Huxtable, C. S. and Hodgson, J. T. (2005. 5) Self-reported work-related illness in 2003/2004: Results from the Labour Force Survey, HSE. http://www. hse. gov. uk/statistics/causdis/swi0304. pdf

33) Self-reported work-related illness in 2003/2004: EXECUTIVE SUMMARY pp32, http://humanics-es. com/swi0304. pdf,

34) Musculoskeletal Occupational Surveillance Scheme. http://www. coeh. man. ac. uk/thor/moss. htm

35) Occupational Physicians Reporting Activity. http://www. coeh. man. ac. uk/thor/opra. htm

36) THE PREVALENCE OF BACK PAIN IN GREAT BRITAIN IN 1998, The Government Statistical Service.

37) PRACTICAL GUIDANCE Introduction Published Case Studies, Victoria Infirmary NHS Trust, Glasgow.

38) The National Health Service. http://www. nhs. uk/Default. aspx

39) THE MANAGERS' GUIDE BACK IN WORK CAMPAIGN. INFORMATION SHEET NO. 2, NHS.

http://www. nhs. uk/backinwork/downloads/infosheet02. pdf

40) The Back in Work campaign, NHS. http://www. nhs. uk/backinwork/contact. htm

41) Better Backs, About back pain, HSE. http://www. hse. gov. uk/betterbacks/aboutbackpain. htm

42 ) Back pain, Transport Salaried Staffs' Association (TSSA).

http://www. tssa. org. uk/article-1. php3?id_article=993

43) HELA ANUAL REPORT 2003, HELA. http://www. hse. gov. uk/lau/pdfs/hela03. pdf

44) HELA SUPPLEMENTARY REPORT 2003, The Health and Safety Executive and Local Authority Liaison Committee (HELA), Health and Safety Offences and Penalties in Local Authority Enforced Sectors. http://www. hse. gov. uk/lau/pdfs/hela0203. pdf

45) MANUAL HANDLING ASSESSMENT CHARTS (MAC), HSE;

46) MANUAL HANDLING guidelines - MMSC022 (imposed by the HSE Manual Handling Operations Regulations 1992)

47) THE PROTECTION AGAINST RISKS IN MANUAL HANDLING, NHS;

48) (Comprising North Peterborough Primary Care Trust and
South Peterborough Primary Care Trust Working in partnership with Peterborough City Council) Manual Handling Policy, Peterborough City Council;

49) OCCUPATIONAL SAFETY, HEALTH AND WELFARE OFFICE, MANUAL HANDLING GUIDELINE DOCUMENT; BIRMINGHAM SPECIALIST COMMUNITY HEALTH NHS TRUST Manual Handling

50) The Rossendale Group, Lifting Equipment and the Law http://www. rossendalegroup. co. uk/forms/RD177. pdf

51) The National Blood Service, Manual Handling Risk Assessment Manual

52) THE UNIVERSITY OF SUSSEX SAFETY COMMITTEE LOCAL RULES for Implementing the MANUAL HANDLING OPERATIONS REGULATIONS 1992

53 ) Policy for Manual Handling Operations Within the University of Paisley

54) Employers' and employees' response to HSE' s Guidance on Manual Handling Operations Regulations (MHOR) Prepared by the University of Liverpool for the Health and Safety Executive

55) Getting to grips with manual handling, HSE. http://www. hse. gov. uk/pubns/indg143. pdf

56) Study Notes: Moving and Handling Legislation Study notes produced in April 2000 by Mike Griffin, last updated 11th April 2004

57) Second Evaluation of the Manual Handling Operations Regulations (1992) and Guidance, Prepared by Entec UK Limited for the Health and Safety Executive;

58) An introduction to risk management Risk Management for smaller businesses, A guide to legislation and best practice;

59) Manual handling at work; a portfolio of leaflets from the Environmental Services, The Tendring District Council Health \& Safety Briefing. http://www. tendringdc. gov. uk/TendringDC/Business/He alth+and+Safety/briefinx. htm

60) WEB Catalogue, Emergency Response Training UK Ltd. http://www. ertuk. co. uk/default. html

61）滝沢恭子，滝沢茂男，他，（2002）, 創動運動用上肢訓練機 兼用リフト機器開発に関する調査研究，バイオフィリアリ ハビリテーション研究，(55-58)

62）大阪府立公衆衛生研究所 労衝衛生部.（平成 14 年 3 月） 「高齢者介護施設などの職員の腰痛·頸肩腕障害などに関 わる質問紙調査」

http://www. iph. pref. osaka. jp/report/kourei-kaigo/

63）山本華代，他（2004）「某製造工場における腰痛と作業姿勢 及び生活習慣との関係」46 巻 78-88 頁産業衛生学雑誌

64）市堰英之, 他, (2005.12.03) 「腰痛対策におけるメンタル ヘルス要因に関する研究」 
http://wwwl. biz. biglobe. ne. jp/ ${ }^{\sim}$ sanpo16/chousa10. htm

65）小森弘, 他, (2001.11.22), 「職業と腰痛症」

http://mcai. med. hiroshima-u. ac. jp/ glbetsu/

66）財団法人日本システム開発研究所，（2005.02）「2003 年度 福祉用具産業の市場規模調査結果の概要」

67）木村哲彦 編，(2002）「介護・依存から自立へ $1 」$ ，シ ビル出版，藤沢，

68) 滝沢茂男, (2006)，「ドイツで第 4 回国際大会を開催」, 時 事通信厚生福祉, 5330, pp4/7,

\section{謝辞}

本論の執筆にあたり，慶應義塾大学環境情報学部武藤 佳恭教授の多大なご指導をいただきました. 修士論文時 には放送大学大学院文化科学研究科政策経営プログラム 松村祥子教授にご指導をいただきました. 心から感謝い たします。また第 4 章 1 項は, 中小企業総合事業団平成 13 年度課題対応新技術研究調査事業『創動運動用上肢訓 練器兼用リフト機器開発に関する研究調査』の交付を得 て，著者を総括研究者として実施した研究報告から縓め ました. 平成 13 年度研究には, 産能大学経営学部松岡幸 次郎教授, 産能大学経営情報学部牛沢賢二助教授, 日本 医科大学木村哲彦教授, (前出) 武藤佳恭教授, 川崎医科 大付属川崎病院森田能子部長, 医療法人帰览会岡本病院 岡本雄三理事長, 木島整形外科医院木島英夫院長, 新潟 医療福祉大学牧田光代教授, 神奈川県立保健福祉大学 (当 時北里大学医療衛生学部) 長澤弘教授, 老健施設せんだ んの丘土井勝幸副施設長, 老健施設ルミエール渡辺展江 理学療法士, 慶応大学病院遠藤敏理学療法士, 立花整形 外科和田里佳理学療法士の参加をいただきました. 共に 研究を進められたことを大変うれしく思っております.

英国統計の調査に当たり, Health and Safety Executive $の$ Epidemiology \& Medical Statistics Unit (EMSU) に所属する Tracy Hamilton 氏を通じ, Paul Buckley 氏より, HSE Statisticsのホームページ紹介を 受けました.

英文翻訳について，小熊千恵さん，当真真紀さん，小 熊千里さん，金川慧子さんにお手伝いいただきました。

本論文発表は多くの皆さんのご協力の賜物と心から感 謝申し上げます。

\section{付録}

法律の条文翻訳記述

1992 年, 健康と安全に関する法律第 2793 号, 「手作業業 務に関する法律 1992」

起草 1992 年 11 月 5 日

議会提出 1992 年 11 月 16 日

発効 1993 年 1 月 16 日
国務大臣はその権限において，第 15 条（1)，(2)，(3)

（a），(5）（a）と（9），80（1），(2）（a）と一覧表 3 の 4 部門の（4）欄，（1）項（a）と（c)，の 8 から，1974 年の労働における健康と安全等に関する法令（「1974 年 法令」）と，またその他国務大臣に属する全ての権限によ り,

（a）1974 年法令による健康と安全委員会で第 50 条 (3) と合致して実行に移された後, 1974 年法令の第 11 条 (2)

(d) の下, 同委員会によって国務長官に提出された議案 を修正なしのままで発布するために，そして

（b）これらの対策が 1920 年の女性, 若者と児童の労働に 関する法令の第 1 条 (2) で容認されているような雇用形 態に当てはまる場合を除いて, 1933 年の児童と若者法令 第 18 条と 1937 年スコットランドの児童と若者法令第 28 条（1）（f）の無効を改正で言及している，1974 法令の 第 80 条（4）に関し，国務長官によって提案されたこの 重要な法律に関する会議の結果,

ここに以下の法律を公布する :

\section{1. 告知と施行}

これらの法律は 1992 年手作業業務に関する法として 告知され，1993 年 1 月 1 日に施行される.

\section{2. 解説}

（1）これらの法律では，条文に定めのない限り，実施 が求められる ;

「傷害」は以下に挙げられるような有毒な, 又は腐食性 の物質による傷害を含まない

（a）漏れ出した，あるいは荷から流出した物質

（b）荷の表面に出ているがしかし荷から漏れ出したり こぼれ落ちたりしていない物質; あるいは

（c）荷の構成要素を成す物質;

そして「怪我をした」ということは以下のように解釈さ れるべきである；

「荷」はいかなる人や動物も含む；

「手作業業務」は手又は身体的力を用いての如何なる運 搬又は荷の取り扱い（上げ下げ，押し引き，運送又は移 動を含む）を意味する。

(2) 従業員に関して，これらの規則によって雇用者に課 されたどんな責任も, 同様に自営の人に対しては自分自 身に関して課される.

\section{3. 規則の適用外範囲}

これらの法律は，遠洋航海の船の船長又は乗組員，又は 船長の指揮下の乗組員の通常の船上活動に関して，その 雇用者には適用されない. 


\section{4. 雇用者の義務}

（1）それぞれの雇用者の責任は以下に規定される;

（a）合理的で実用的であるとしても, 雇用者はその従業 員にケガをさせる危険性を伴う如何なる手作業業務の請 負を避けるべき必要があり，あるいは；

（b）合理的で実用的でない場合でも, 雇用者が従業員に ケガをさせる可能性のある如何なる手作業業務を請負う 必要性を避けるべきであり,

(i) 従業員に業務させるためには手作業業務の適切で十 分な査定を行い, 法律の第 1 条 1 項で特定されている要 素, 同 2 項に対応する記述で特定された要求を考慮しつ つ,

（ii）合理的で現実的な最低限レベルの手作業業務を行 うべき従業員がケガをする危険性を減らすための適切な 手順を取り，そして

（iii）一般的な指示が与えられた, 前述した手作業業務 を行うべき従業員が適切な手順を取り, そして明確な情 報に基づいて適切に実施するために

（ aa）それぞれの荷の重量, そして

（bb）その比重において重心が中央にない全ての荷の 最重量部の側面

（2）本条の（1）（b）（i）にかかる查定は, 以下の場合 にそれを行った雇用者によって再検討されるべきである （a）もはや効力がないとみなされる理由がある；あるい は

（b）関連する手作業業務の重要な変更があった； そしてその結果評価の如何なる変更が必要になった場合 においても，該当する雇用者は査定しなければならない

\section{5. 従業員の責務}

業務に従事中のそれぞれの従業員は, 本法第 4 条 (1) (b)

（ii）に従って，その雇用者により当該従業員の使用の ために提供された全ての仕事のシステムを，完全で適切 に使用しなければならない.

\section{6. 免除証明書}

（1）国防国務長官は，国家機密に関する懸念により，免 除を記載した証明書により免責できる

（a）本法第4条によって課された国軍，いかなる他国軍, 又は必要により組織された司令部; あるいは

（b）本法第 5 条によって課された国軍の誰も，いかなる 他国軍人，又は必要により組織された司令部要員;

(2)この法律において, そして本項の補助項 (a) 及び補 助項（b）に特定された全ての免除は，条件と指定された 期間に従って有効とされ，いかなる場合でも，当該の国 務長官の宣言によって無効にされる得る

（a）「国軍」は1952年[5]の訪問他国軍法令の第 12 条（1）と同じ意味を有し;

（b）「司令部」は1965年[6]の訪問他国軍と国際司令 部（法の適用）令の第 3 条（2）と同様の意味を有し; そして

（c）「司令部要員」は，1964年[7]の国際司令部と国 防組織令の一覧の 1 項（1）と同様の意味を有し; そし $\tau$

（d）「他国軍」は，1952 年の訪問他国軍法令の目的実施 のための第一部の全条項と同じ意味を有する

\section{7. 英国外での法の有効性拡張}

本法の第 3 条は, 1974 年健康安全労働法の第 1 条から第 59 条までと第 80 条から第 82 条までは 1974 年健康安全 労働法 (英国の外の適応) に関する 1989 年命令により英 国内同様に法適応され，英国外で国内同様に，行動に対 して効力を持つ

\section{8. 廃止と撤回}

（1）これらの法律ついての一覧表 2 の 1 部門，1欄で規 定される立法は, 同表の 3 欄対応する項目で指定された 範囲で無効にされる.

（2）これらの法律ついての一覧表 2 の 2 部門，1欄で規 定される法律は, 同表の 3 欄対応する項目で指定された 範囲で廃止される。

国務長官の命令によって署名 パトリック・ママクローリン 議会議決，雇用省国務長官関連議案 1992 年 11 月 5 日

附則

[1] 1974C 7; 第 1 条 (1), 第50 条（3）と第 80 条 (4) が雇用保護法令 1975 (c. 71), 付表 15, 第6 条と第 16 条

（3）と第 19 条によってそれぞれ改正された.

[2] 1933 c. 12.

[3] 1937 c. 37.

[4] 1920 c. 65.

[5] 1952 c. 67.

［6］これらに法律に関係がない改正を S. I. 1965/1536 として実施した

[7] 1964 c. 5.

[8] S. I. $1989 / 840$. 


\title{
APPROACH OF THE ESTABLISHED CARE SYSTEM ON THE AGED SOCIETY BY DEVELOPING THE REGULATIONS COMPARATIVE STUDY BETWEEN BRITISH AND JAPANESE REGULATIONS
}

\author{
TAKIZAWA, Shigeo ${ }^{1}$, Yoshiyasu TAKEFUJI ${ }^{2}$
}

${ }^{1}$ M.A.. (Civil Technology) Visiting Researcher, Keio University, The Keio Research Institute at SFC (E-mail:takizawa@civilnet.org)

${ }^{2}$ Ph.D (Neural and multimedia center) Professor, Keio University, Faculty of Environmentral Information

It is important to increase care power while keeping care worker's health to enable care of disabled elderly in home in order to maintain a low birthrate aged society stability. Up to 80 percent of the home care workers have been afflicted by lumbago in Japan. Research of British regulations where the remarkable reduction of musculoskeletal-disorders (MD) has been realized has been compared to Japanese research related to the labor regulations. The consciousness, measure and its present condition towards MD reduction were investigated and clarified in the care work front. In order to decrease MD within the field of nursing and home care in Japan, the necessity for maintenance of the regulations was proved and described.

Key Words: The developing regulations, the care workers' accident, Decrease of the musculoskeletal disease, super aged society, Prevention of the society collapse 